\title{
Partial identification of a peptide from Lacticaseibacillus casei using MALDI TOF and it's cytotoxic activity against MDA-MB-231 cell line
}

\author{
Jannatul Firdous Siddique (D), Mohanasrinivasan Vaithilingam* \\ School of Bio Sciences and Technology, Vellore Institute of Technology, Vellore, India.
}

\section{ARTICLE INFO \\ Article history: \\ Received on: October 1, 2021 \\ Accepted on: November 20, 2021 \\ Available online: February 15, 2022}

\section{Key words:}

Chromatography, RP-HPLC, FT

IR, MS-MALDI, cytotoxic

\begin{abstract}
The current study focused to extract and purify the peptide of interest efficaciously from Lacticaseibacillus casei. The peptide of interest was partially identified and checked for anti-cancer activity using MDA-MB-231 triple negative breast cancer cell line. To begin with, it was purified via ammonium sulfate precipitation, ultrafiltration, and gel filtration chromatography. It was partially identified using mass matrix assisted laser desorption/ ionization-mass spectrometry (MS-MALDI) and checked for cytotoxic activity using (3-(4,5-Dimethylthiazol2-yl)-2,5-Diphenyltetrazolium Bromide) assay. As an outcome, the active part collected after ultra-filtration, 880 $\mu \mathrm{g} / \mathrm{ml}$ of protein content with $15 \mathrm{~mm}$ zone diameter, was loaded on sephadexG50 column. The purified protein content was found to be $118 \mu \mathrm{g} / \mathrm{ml}$ with $15 \mathrm{~mm}$ of zone of inhibition against Listeria monocytogenes. A peak was obtained at a retention time of 9.371 minutes on subjected to high performance liquid chromatography. The result of MS-MALDI revealed it as an unnamed peptide with $75 \%$ query sequence similarity with the hypothetical protein of Lactobacillus reuteri. The cytotoxic study revealed its potential as an anti-cancer peptide, with the $\mathrm{IC}_{50}$ value of $108 \mu \mathrm{g} / \mathrm{ml}$ for MDA-MB-231 cancer cell line. In conclusion, this is the first report of this unknown peptide which showed both antibacterial and cytotoxic activity. It may act as a promising agent and can be further explored in future.
\end{abstract}

\section{INTRODUCTION}

Cancer is still one of the deadliest diseases with high mortality rate [1]. Cancer treatment, such as radiation therapy, chemotherapy or medicine come with pain and prolonged suffering. In case of traditional therapeutics, it has showed an immense failure due to the resistance by the cancer cells. Hence, an intent need has arisen to find a cure or an alternative novel metabolite which will selectively target the cancer cells as stated by Raguz and Yague [2].

One of the trending metabolites like bacteriocin has come to light. Vast ongoing research are being carried forward to discover its role against cancer cell lines. Lactic acid bacteria produce bacteriocins and those are positively charged peptides. It has anti-microbial activity and are, ribosomally synthesized, narrow or broadspectrum, antimicrobial peptides [3]. Bacteriocins are broadly

\footnotetext{
*Corresponding Author

Mohanasrinivasan Vaithilingam, School of Bio Sciences and Technology, Vellore Institute of Technology,Vellore, India.E-mail:v.mohan@vit.ac.in
}

classified into three classes: class I post translationally modified, class II unmodified, and class III $<10 \mathrm{kDa}$ in size as described by Arnison et al. [4] and Cotter et al. [5].

It acts against the closely related species and act against the negatively charged cancerous cells other than normal cells as stated by Kaur and Kaur [6]. Cancer cell surface possess negatively charged ubiquitous components in a significant amount. Components like gangliosides, anionic phosphatidyl serine, $O$-glycosylated mucins, and heparin sulphates, whereas in the outer surface of non-cancer cells, components like neutral phospholipids including sphingomyelins and phosphatidyl choline are present. In case of the inner surface amino-phospholipids can be found as described by Riedl et al. [7].

For the first time, as observed by Farkas-Himsley and Cheung [8] bacteriocin proved to have toxic effect on eukaryotic cells. In addition, the effect on mammalian cells has also been reviewed earlier by Cornut et al. [9]. As per the report of Singh et al. [10] strain GI-9 belong to the genus Brevibacillus sp. produced bacteriocin named laterosporulin which showed broad spectrum 
antibacterial activity. Based on its biochemical and genomic characterization, it was discovered as a novel bacteriocin.

In the study, as carried by Baindara et al. [11] the anti-cancer activity of LS10 a defensin like peptide obtained from Brevibacillus sp. strain SKDU10 was examined against varied cancer cell lines, such as MCF-7, HEK293T, HT1080, HeLa, and H1299. It was revealed, the bacteriocin LS10 induced apoptosis at $2.5 \mu \mathrm{M}$ concentration. The study has also confirmed both the necrotic and apoptotic death of the cancer cells at higher and lower concentration respectively.

Another report suggested the lethal effect of bacteriocin, which showed a visible decrease of the sensitive indicator strain, Mycobacterium diernhoferi ATCC 19340 by the bacteriocin. In this study, Saito et al. [12] demonstrated the inhibition of the growth of HeLa-S3 cells by the bacteriocin preparation.

The identification of the unknown active peptide is indeed necessary to carry out the research commercially in future. Hence, its identification is one of the important parameters to learn in depth about the unknown peptide. Similar finding like, De Giani et al. [13] reported a study in identifying a bacteriocinlike compound from Lactobacillus plantarum, which showed antimicrobial activity and cytotoxic effects on normal and cancerogenic human intestinal cells.

The study was continued with the major cancer cell line such as triple negative breast cancer MDA MB-231 for the initial screening of cytotoxic activity.

In previous studies, Lacticaseibacillus casei MH137744 was isolated from fermented Cumin by authors. Effect of $\mathrm{pH}$, temperature and enzymes were checked. Peptide extracted from $L$. case $i$ was proved to be of proteinaceous in nature. The bacteriocin activity was found to be $800 \mathrm{AU} / \mathrm{ml}$.

The current research dealt with the purification of the peptide and checks its activity against major food borne pathogens as preliminary screening, due to its pore forming characteristics in the bacterial cell wall. This study was conducted to check the cytotoxic role against triple negative breast cancer MDA-MB-231 and partial identification of the unknown peptide.

\section{MATERIALS AND METHODS}

\subsection{Sample Preparation}

The isolate L. casei MH137744 was retrieved from 20\% (v/v) of glycerol stock and sub cultured in triplicate to carry out the further assays. It was grown in $200 \mathrm{ml}$ of De Man, Rogosa and Sharpe medium for 48 hours at $30^{\circ} \mathrm{C}$. The culture was centrifuged $\left(13,000 \mathrm{rpm}, 20\right.$ minutes, $\left.4^{\circ} \mathrm{C}\right)$ and the cell free supernatant (CFS) was collected and purified via three-step purification step, ammonium sulphate precipitation, ultrafiltration and gel filtration chromatography using sephadexG50. After each purification step, the protein concentration was measured using Lowry's method at $660 \mathrm{~nm}$ using bovine serum albumin as a standard and the antibacterial activity was checked by agar well diffusion assay (AWDA) using Listeria monocytogenes as an indicator organism.

\subsection{Purification}

\subsubsection{Ammonium sulfate precipitation}

The supernatant was subjected to ammonium sulfate precipitation. Throughout the experiment the supernatant was kept in ice, and the powdered ammonium sulfate was added slowly with continuous stirring, for 1 hour. The ammonium sulfate was added, consecutively for 3 days, starting from $0 \%$ to $30 \%, 30 \%$ to $60 \%, 60 \%$ to $80 \%$, $80 \%$ to $100 \%$. Each day the precipitate and supernatant were collected and checked for antibacterial activity using AWDA.

The supernatant was desalted using sephadexG15 before being loaded to the fine ultra-filtration membrane. The active fractions were loaded onto the column bed $(15 \times 2.5 \mathrm{~cm})$ packed with Sephadex G10 for desalting using $50 \mathrm{mM}$ of sodium acetate buffer as an eluent ( $\mathrm{pH}$ 5.5). The sample were collected, at a flow rate of $0.5 \mathrm{ml} /$ minute and subjected to ultra-filtration technique.

\subsubsection{Ultra-filtration technique}

The ultra-filtration technique was carried out using 10 and 3 $\mathrm{kDa}$ ampicon centrifugal unit (Sigma-Aldrich) consecutively and centrifuged $\left(4,000 \times \mathrm{g}, 30\right.$ minutes, $\left.4^{\circ} \mathrm{C}\right)$. The permeate and retentate were both collected and checked for protein content using Lowry's method and antibacterial activity by AWDA.

\subsubsection{Gel filtration chromatography using sephadexG50}

The active fractions were loaded onto the column bed $(15 \times 2.5$ $\mathrm{cm}$ ) packed with Sephadex G50 for gel filtration chromatography using $50 \mathrm{mM}$ of sodium acetate buffer as an eluent (pH 5.5). The 20 fractions were collected, at a flow rate of $0.5 \mathrm{ml} /$ minute and checked at 220/280 $\mathrm{nm}$ in UV visible spectrophotometer (Remi) for the presence of peptide.

\subsection{Partial Identification of the Peptide}

\subsubsection{UV-visible spectrophotometer}

Initially, the crude CFS containing the peptide of interest was analyzed using UV Visible spectrophotometer. The spectrum obtained given an overview idea of the peptides of interest present in the crude supernatant. All amino acids absorb at $200-220 \mathrm{~nm}$ due to the $\mathrm{C}=\mathrm{O}$ group. But, high density of spectrum at $220 \mathrm{~nm}$, suggest the presence of peptide bond (amide) which has given absorbance. It can also be inferred as, the aromatic amino acid (Tyr, Phe, and Trp), absorbed UV with two different peaks. The peak at $\sim 270-280 \mathrm{~nm}$ is due to the conjugation system of the aromatic ring and the absorbance peak at lower wavelengths is attributed to carboxylic acid moiety of the amino acid. However, the presence of disulfide bridges (also a result of oxidation) may have showed a weak extinction factor at $280 \mathrm{~nm}$.

\subsubsection{Fourier transform infra-red (FTIR) analysis}

Surface functional groups of purified peptides were unraveled by Perkin-Elmer infrared spectrophotometer (India). Purified peptide was lyophilized and mixed with potassium bromide (spectroscopic grade). Pellet was prepared with the size of about 
10-13 mm diameter and $1 \mathrm{~mm}$ thickness. Sample was scanned in transmission mode with a resolution of $4 \mathrm{~cm}^{-1}$ at $4,000-500 \mathrm{~cm}^{-1}$ range and functional groups were compared with the literature.

\subsubsection{Reverse phase-high performance liquid chromatography (HPLC)}

A sample volume of $20 \mu$ of purified and partially purified were injected simultaneously in HPLC (Detector-UV VIS 2487; Column length-250 mm-C18; Make: Water; Model No: 1525 Pump; elution temperature, flow rate $300 \mu \mathrm{l} / \mathrm{minute}$; wavelength $-220 / 280 \mathrm{~nm}$ ) peptide concentration of $100 \mu \mathrm{g} / \mathrm{ml}$ dissolved in $50 \mathrm{mM}$ of sodium acetate buffer ( $\mathrm{pH}$ 5.5). The HPLC profile was recorded out using 1:1 acetonitrile:water constituted with trifluoracetic acid $0.05 \%$. The purified peptide of interest was lyophilized and stored at $-80^{\circ} \mathrm{C}$ for further assay.

\subsubsection{MS MALDI analysis}

The peptide of interest after trypsinization was directly subjected for the analysis by MS MALDI (BRUKER Ultra flex III MALDI TOF TOF). The sequence was obtained from mascot search and the sequence homology was performed using basic local alignment search tool (BLAST).

\subsection{Cytotoxic Activity of the Peptide Using MTT Assay}

The purified bacterial peptide was checked for cytotoxicity using 3-(4,5-dimethylthiazol-2-yl)-2,5-diphenyltetrazolium bromide for (MTT) assay [14] against major cancer cell line, triple negative breast cancer MDA-MB-231 an epithelial human breast cancer cell line.

The cell line (Sigma-Aldrich) was maintained in Dulbecco's modified eagle medium with $10 \%$ fetal bovine serum at $37^{\circ} \mathrm{C}$ and $5 \% \mathrm{CO}_{2}$. Cells were trypsinized and $5 \mathrm{ml}$ of complete media was added to the trypsinized cells. The cells were centrifuged at 500 rpm in the swinging bucked rotor $(\sim 400 \times \mathrm{g})$ for 5 minutes.

The media was removed and later resuspended with complete media. The $100 \mu \mathrm{l}$ of cells were added into each well and left for incubation for overnight.

On the second day, the cells were treated with 50, 100, 250, and $500 \mu \mathrm{g} / \mathrm{ml}$ of peptide of interest (in triplicate), respectively, and the percentage viability was calculated as described by Sharma et al. [15]. The final volume was maintained at $100 \mu \mathrm{l}$ per well. On the third day, $20 \mu 1$ of $5 \mathrm{mg} / \mathrm{ml}$ MTT was added to each well. The setup was incubated for 4 hours at $37^{\circ} \mathrm{C}$ without any disturbance. The MTT solvent of $150 \mu \mathrm{l}$ was added and the cells were agitated on orbital shaker for 15 minutes. The absorbance was checked at $570 \mathrm{~nm}$ with a reference filter of $620 \mathrm{~nm}$ [16].

\section{RESULTS AND DISCUSSION}

In continuation of the previous study, a large number of LAB were isolated from fermented Cuminum cyminum or commonly known as cumin, which were also found to be an active hub of bacteriocin like substance.

As studied earlier, by the authors among 110 isolates one potent strain VITCM05 was selected based on their broad-spectrum antibacterial activity against major food borne pathogens. Using BLAST, it showed $93 \%$ maximum identity and $E$-value equal to 0.00 for all closely related taxa. The isolate was identified as $L$. casei, MH137744 and the CFS extracted was of proteinaceous in nature. Lacticaseibacillus casei has been transferred to a new genus Lacticaseibacillus (the L. casei group). This group comprises 26 species and two subspecies as reported by Zheng et al. [17].

The $200 \mathrm{ml}$ of culture L. casei, $16 \times 10^{7}$ cells $/ \mathrm{ml}$ was centrifuged and the extracted CFS was consist of extracellular peptide. The total protein content was found to be $3.4 \mathrm{mg} / \mathrm{ml}$ with $25 \mathrm{~mm}$ zone of inhibition against L. monocytogenes MTCC5260.

As peptides are small in nature, it generally secretes out of the cell membrane, and thus can be found in extracellular environment as stated by Daw and Falkiner [18].

\subsection{Purification}

The purification was carried out via ammonium sulfate precipitation, ultrafiltration, and gel filtration technique. Simultaneously in each step, the activity was checked using AWDA, which showed a clear zone of inhibition for the active portions. In step 1 and 2 of purification, the yield was found to be $100 \%$, due to negligible loss of peptide. Simultaneously, the specific activity increased with the decrease of yield as can be observed in Table 1.

The CFS was subjected for ammonium sulfate precipitation till the protein of interest gets precipitated out. Interestingly, even at $100 \%$ of saturation, the protein of interest did not precipitate out

Table 1. Purification table.

\begin{tabular}{ccccccccc} 
Sample & Vol $(\mathbf{m l})$ & $\mathbf{m g}^{-1} \mathbf{~ m l}$ & $\begin{array}{c}\text { Total protein } \\
(\mathbf{m g})\end{array}$ & $\begin{array}{c}\text { Activity units } \\
(\mathbf{A U} / \mathbf{m l})\end{array}$ & $\begin{array}{c}\text { Total activity } \\
(\mathbf{A U})\end{array}$ & $\begin{array}{c}\text { Specific activity } \\
(\mathbf{A U} / \mathbf{m g})\end{array}$ & $\begin{array}{c}\text { Purification (fold) } \\
\text { Yield (\%) }\end{array}$ \\
$\begin{array}{c}\text { Crude } \\
\text { Ammonium Sulphate }\end{array}$ & 200 & 3.4 & 720 & 800 & 160,000 & 222.222 & 100 & 1 \\
$\quad$ ppt. & 100 & 1.94 & 194 & 1,600 & 160,000 & 824.742 & 0.371 & 100 \\
$\begin{array}{c}\text { Desalted } \\
\text { Ultrafiltration }\end{array}$ & 10 & 1.4 & 14 & 1,600 & 16,000 & $1,142.857$ & 5.142 & 10 \\
Gel filtration & 10 & 0.880 & 4.4 & 3,200 & 32,000 & $7,272.727$ & 32.727 & 20 \\
\hline
\end{tabular}

The purification table shows the specific activity of the purified peptide was increased to $27,118.64$ when compared to the crude specific activity of 222.22 , the final step showed the purified peptide has total Activity (AU) 6,400 with 4\% of yield and 122.03 purification fold. 
as a pellet and remained in the supernatant. The pellet showed no zone of inhibition against the indicator organism but the remaining supernatant showed $20 \mathrm{~mm}$ of zone of inhibition. The protein content was found to be $1.94 \mathrm{mg} / \mathrm{ml}$. In this case, it can also be stated that, most of the proteins has already been excluded as a pellet so very few and only low molecular weight proteins were left out in the supernatant. Hence, the yield was found to be $100 \%$ even after performing ammonium sulfate precipitation, as can be seen in Table 1.

The supernatant was desalted using Sephadex G15, protein content was found to be $1.4 \mathrm{mg} / \mathrm{ml}$ with $15 \mathrm{~mm}$ zone of inhibition. On being subjected to ultrafiltration $\left(4,000 \times \mathrm{g}, 30\right.$ minutes, $\left.4^{\circ} \mathrm{C}\right)$ using 10 and $3 \mathrm{kDa}$ ampicon centrifugal unit (Sigma-Aldrich) consecutively. Both the permeate and retentate were pulled out and checked for its content and antibacterial activity. The permeate obtained from $10 \mathrm{kDa}$ showed activity of $15 \mathrm{~mm}$ with a content of approximate $980 \mu \mathrm{g} / \mathrm{ml}$ and retentate showed no activity, which indicates the peptide to be of less than $10 \mathrm{kDa}$. Further the active permeate fraction were ultrafiltered with $3 \mathrm{kDa}$ membrane. There were no permeate obtained and the retentate showed a $15 \mathrm{~mm}$ of zone of inhibition with $880 \mu \mathrm{g} / \mathrm{ml}$ of protein content. From the observation it is evident that the protein of interest range between 4 and $9 \mathrm{kDa}$.

The active fraction eluted from the gel filtration chromatography showed a $15 \mathrm{~mm}$ of zone of inhibition with a protein content of $118 \mu \mathrm{g} / \mathrm{ml}$.
The CFS showed a specific activity of 222.222 with a 160,000 $\mathrm{AU}$ and as the purification step was carried out, gradually specific activity increased to 7,272.727 with $20 \%$ yield and $32,000 \mathrm{AU}$. In the final step of purification, the total peptide content of $0.23 \mathrm{mg}$ showed $6,400 \mathrm{AU}$ with a vast increase in specific activity of 27,118 with maximum of $4 \%$ yield. As reported by Sabo et al. [19], the AU 3,200 with yield of $2 \%$ is quite less when compared with this present work.

\subsection{Partial Identification of the Peptide}

\subsubsection{UV-visible spectrophotometer}

In this study, the crude CFS was checked spectrophotometrically using UV visible spectrophotometer. The reading was captured at a range of 220-300 $\mathrm{nm}$. The sharp absorption at $220 \mathrm{~nm}$, showed a possibility for the presence of peptide, as shown in Figure 1.

\subsubsection{FTIR analysis}

In the analysis of FTIR, the IR absorbance was checked in the range $500-4,000 \mathrm{~cm}^{-1}$ of wavelength. The FTIR spectra peaks at $1,542,1,630$, and $3,270 \mathrm{~cm}^{-1}$ showed the existence of peptide bonds in the sample as can be observed in Figure 2.

The wavelength $1,542.06 \mathrm{~cm}^{-1}$ reveals an amide II (generally a $\mathrm{NH}$ deformation) which can be found in the range of 1,540-1,550 $\mathrm{cm}^{-1}$. It is also used to determine the secondary structure of the protein, which also reveals it to be $\alpha$ helix in nature. The major functional group, (amide I) group range from 1,625-1,640 $\mathrm{cm}^{-1}$,

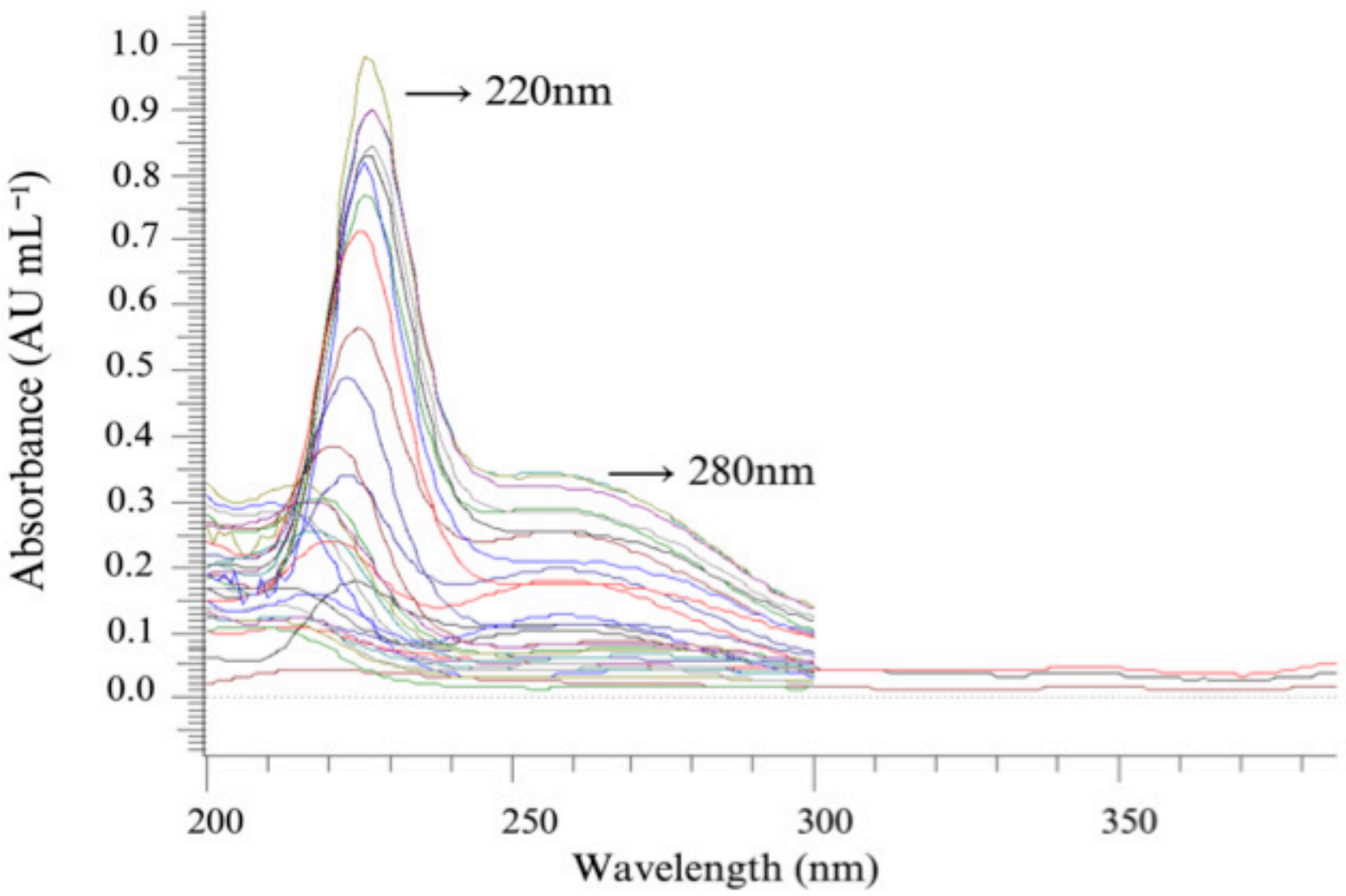

Figure 1. On the $\mathrm{X}$-axis, " $\mathrm{nm}$ " is plotted, whereas on the $\mathrm{Y}$ axis, the absorbance unit is shown $\left(\mathrm{AU} \mathrm{m}^{-1}\right)$. The figure depicts the crude supernatant were a mixture of peptide or protein, as it showed absorbance at 220 and $280 \mathrm{~nm}$ simultaneously. The UV visible spectrophotometer reading captured at 220-300 nm. Sharp absorption at 220, $280 \mathrm{~nm}$ indicates the total concentration of the crude extract. 


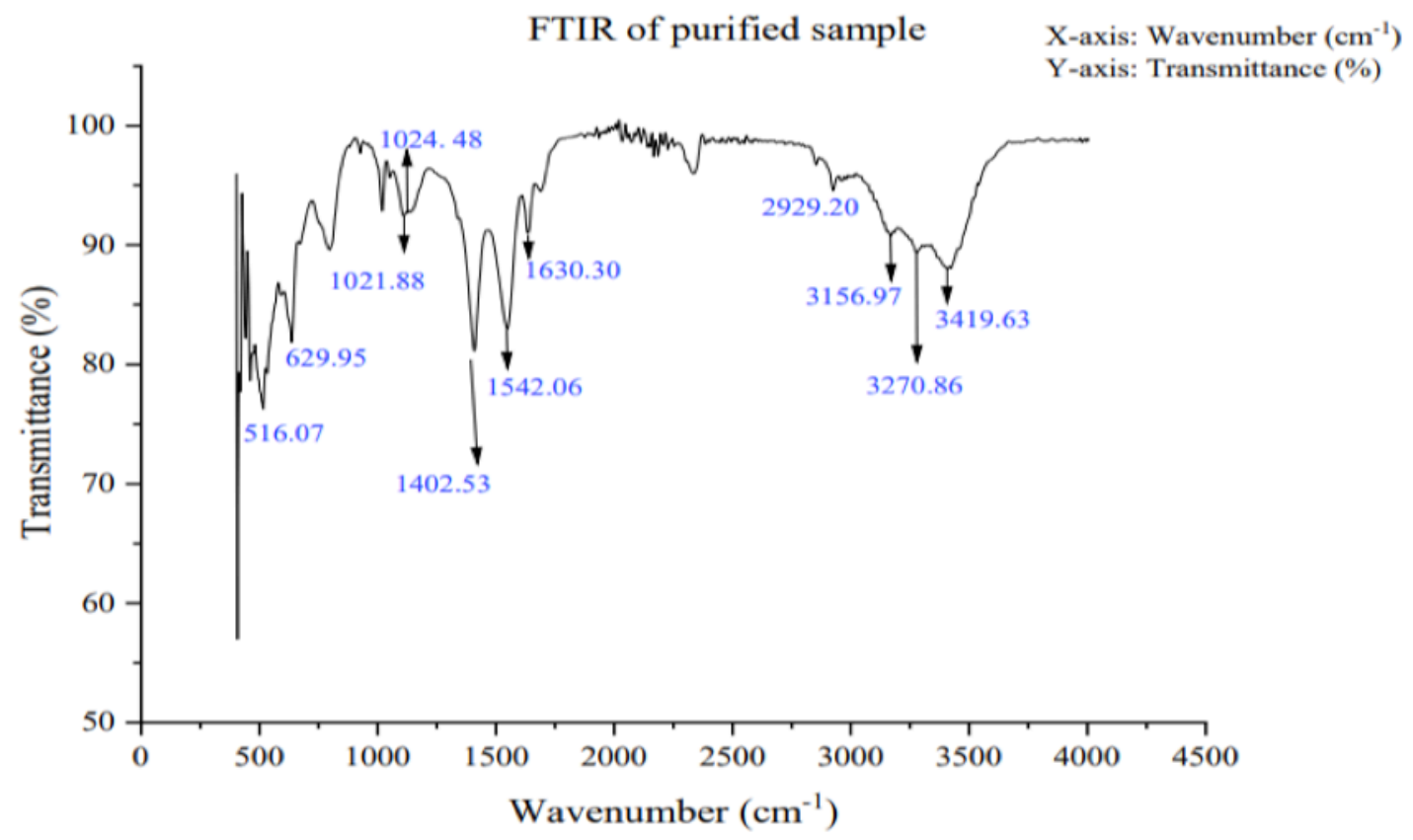

Figure 2. The FTIR spectra of showed peaks at $1,542,1,630$, and $3,270 \mathrm{~cm}^{-1}$ shows the the existence of peptide bonds in the sample. Wavelength versus transmittance $\%$ is plotted, and the respective peak depicts the functional bonds.

which is specifically used to determine structure. The peak at $1,630.30 \mathrm{~cm}^{-1}$ reveals the presence of primary amino group (amide I) $\mathrm{C}=\mathrm{O}$ stretch $[20]$. We can also conclude the presence of a $\beta$ sheet, as a secondary protein structure. The peak at $3,156 \mathrm{~cm}^{-1}$ confirmed aromatic $\mathrm{C}-\mathrm{H}$ stretch as reported by Coates [21].

Generally, in this range of $3,300-3,500 \mathrm{~cm}^{-1}$, the wavelength shows a NH stretch. Greater than $3,400 \mathrm{~cm}^{-1}$, at higher wavelength, an asymmetric stretch of (R-NH2) wavelength generally can be found. The presence of a peak at $3,419.63 \mathrm{~cm}^{-1}$ depicts a presence of amide stretch as well. Further few peaks can be seen in the fingerprint region, below $1,500 \mathrm{~cm}^{-1}$. The $1,402.53 \mathrm{~cm}^{-1}$ wavelength reveals $\mathrm{OH}$ bend.

\subsubsection{Reverse phase-HPLC}

Figure 3a shows the peak / presence of peptide; purified and Figure 3 b partially purified sample checked at $220 / 280 \mathrm{~nm}$ in HPLC. A peak was obtained at 9.371 minutes, was pulled out and checked for concentration and antibacterial activity.

The partially purified sample showed a number of peaks, at different retention time, such as at 1.697, 7.983, 8.462, 8.803, 9.072 th minute, which represented, number of peptides present in the sample. In comparison, a sharp single peak was obtained at a retention time of 9.371 minute, which was further pulled off for later study. Similar study was also carried out by Zhang et al. [22] where instead of ultrafiltration membrane, they have used dialysis membrane flowed by AKTA (GE Healthcare, Uppsala, Sweden), equipped with SP Sepharose Fast Flow column, for purification.

In this study, dialysis method has been omitted due to its inability to retain the low molecular weight metabolites.

\subsubsection{Mass matrix assisted laser desorption/ionization-mass spectrometry (MS-MALDI) analysis}

The active fraction was further subjected to MS MALDI. Using the search parameters, the peptide of interest was identified as using MS MALDI analysis using the peaks obtained: 780.389, 879.466, 951.507, 1,105.580, 1,252.607, 1,310.0466, 1,412.697, $1,542.731$, and $1,719.854$.

\section{Search Parameters used as given below:}

Type of search: Peptide Mass Fingerprint, Enzyme: Trypsin, Fixed modifications: Carbamidomethyl (C)

Variable modifications: Oxidation (M), Mass values:

Monoisotopic, Protein Mass: Unrestricted

Peptide Mass Tolerance: $\pm 100 \mathrm{ppm}$

Peptide Charge State: 1+; Max Missed Cleavages: 2

Number of queries: 14; Selected for scoring: 13

In Figure 4 MS MALDI analysis showed a major peak in 1,252.607 $\mathrm{m} / \mathrm{z}$. Corresponding to that $\mathrm{m} / \mathrm{z}$ value peptide sequence coverage were checked by MASCOT search as given. Remaining peak search revealed no result. Moreover, the Mascot result revealed, the peptide sequence similarity of $75 \%$ with the hypothetical protein of Lactobacillus reuteri.

Figure 5(a) and (b) confirms that the peptide showed no exact similarity with the already discovered protein, peptide or even with any type of bacteriocin as shown in Figure 6 using BLAST analysis. The peptide showed $75 \%$ sequence similarity with the hypothetical protein of $L$. reuteri $(p<0.5)$. The partial protein sequence, were aligned using BLAST tools. Hence, it is the first 

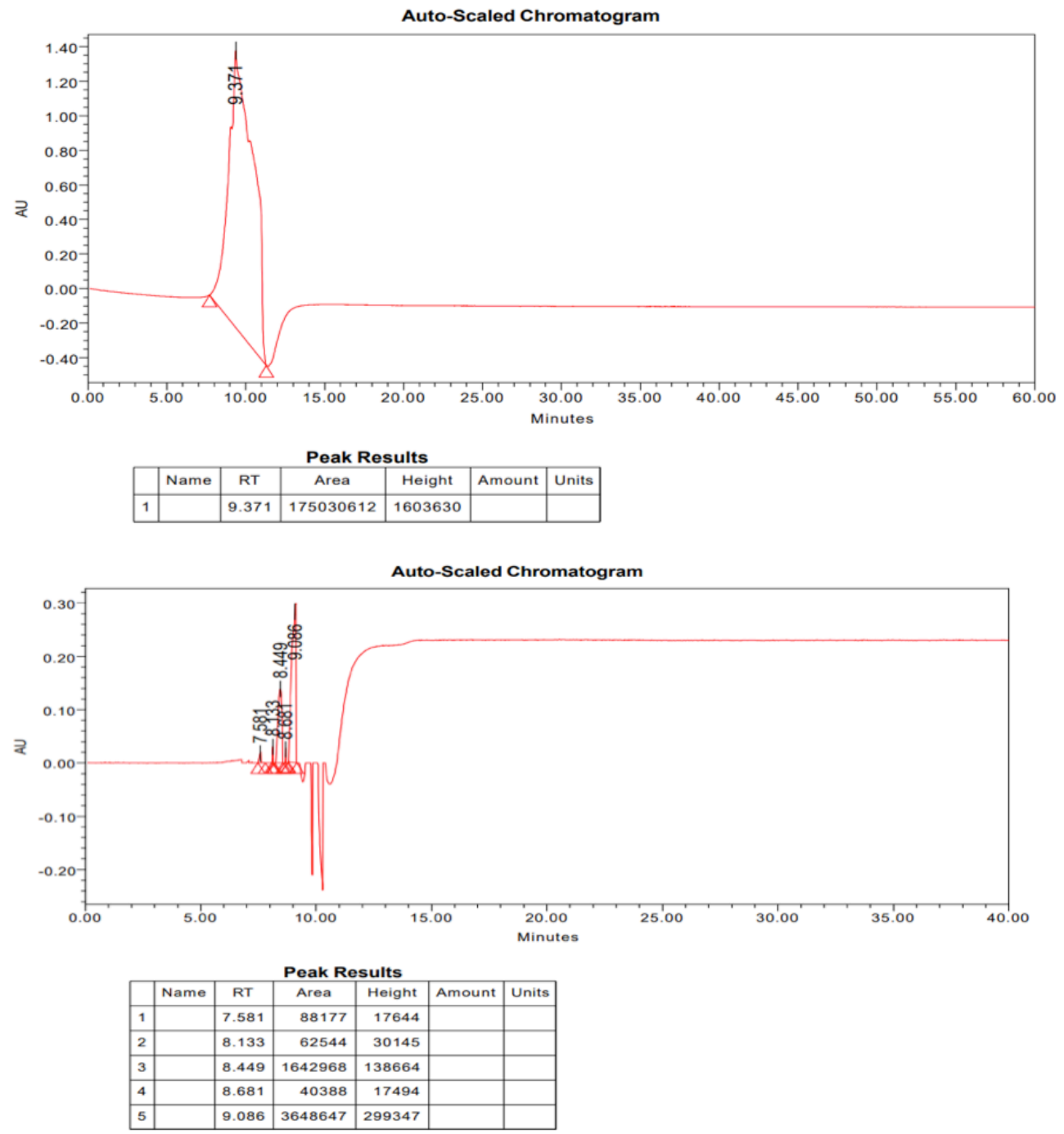

Figure 3. (a) The purified (b) partially purified sample checked at 220/280 nm in HPLC.

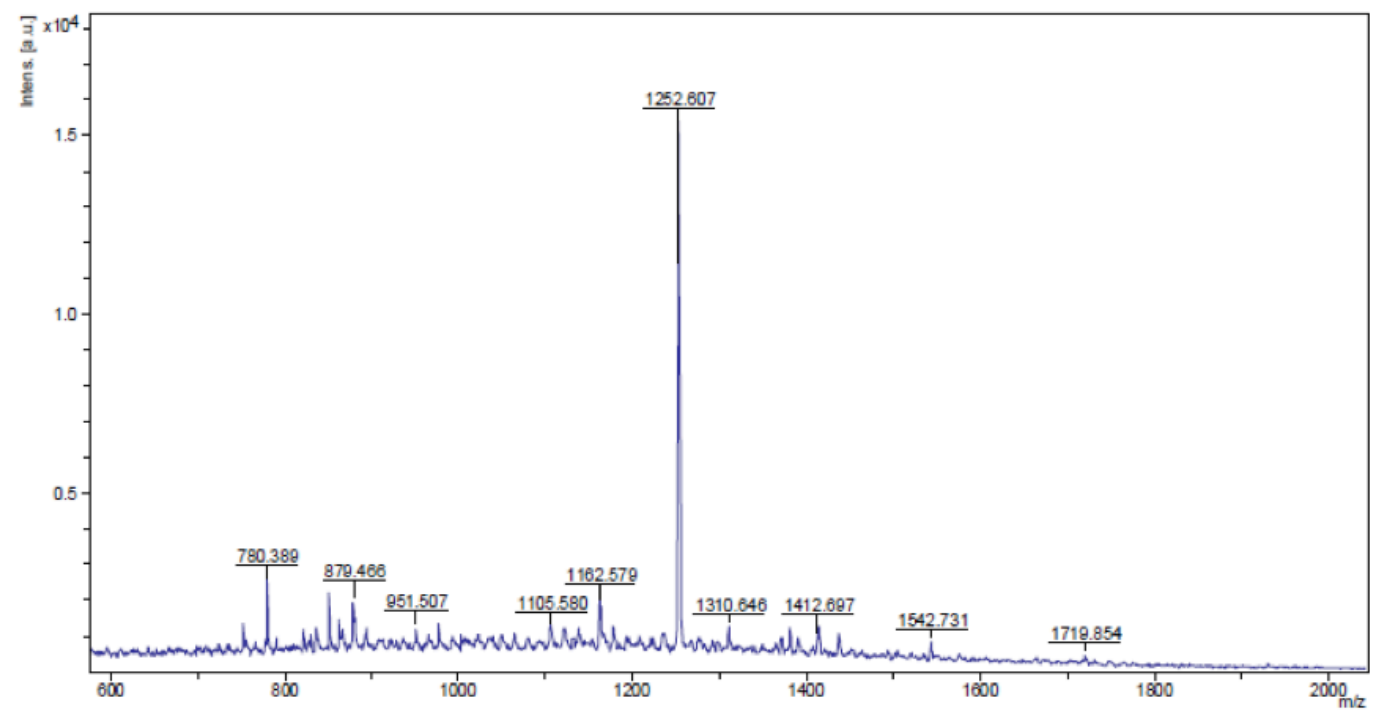

Figure 4. MS MALDI analysis showed a major peak in 1,252.607 m/z. 
ПMARRX MASCOT Search Results

\section{Protein View: CUR41808.1}

hypothetical protein LRLP16767_LRLP167_00157 [Lactobacillus reuteri]

$\begin{array}{ll}\text { Database: } & \text { NCBlprot } \\ \text { Score: } & 72 \\ \text { Expect: } & 1.3 \\ \text { Monoisotopic mass }\left(M_{\text {f }}\right): 5792 \\ \text { Calculated pI: } & 4.93 \\ \text { Taxonony: } & \underline{\text { Lactobacillus reuteri }}\end{array}$

Sequence similarity is avallable as an NCBI BLAST search of CUR41808.1 against nr.

Search parameters

MS data file: peaklist.xnl

Enzyme: $\quad$ Trypsin: cuts C-term side of KR unless next residue is $P$.

Fixed modifications: Carhamidomethwl(C)

Variable modifications: Oxidation (M)

Mass values searched: 14

Mass values matched: 5

\section{Protein sequence coverage: $75 \%$}

Matched peptides shown in bold red.

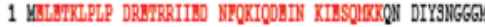

Unformatted sequence string: 49 residues (for pasting into other applications).

Sort by 0 residue number $\quad 0$ increasing mass 0 decreasing mass

Show 0 matched peptides only $\mathrm{O}$ predicted peptides also

\begin{tabular}{|c|c|c|c|c|}
\hline Start - Ind & Observed & $\operatorname{Mr}($ expt) & lir (calc) & ppn II Peptide \\
\hline $2-12$ & 1310.6461 & 1309.6388 & 1309.7241 & -65.11 M. MLETKLPLPOR.1 \\
\hline $7-16$ & 1252.6072 & 1251.5999 & 1251.7047 & -83.82 X.LPLPDRUTRR.I \\
\hline $16-24$ & 1162.5795 & 1161.5722 & 1161.6142 & -36.21 R.RIIGDNOR.I \\
\hline $25-38$ & 1719.8544 & 1718.8471 & 1718.8872 & 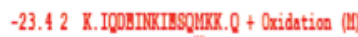 \\
\hline $32-38$ & 879.4659 & 878.4586 & 878.4531 & 6.241 R. IBSQMKX. Q + Oxidation (II) \\
\hline
\end{tabular}

No match to: $780.3898,851.4281$, 851.4438, 951.5074, 978.5131, 1105.5800, 1258.5710, $1412.6970,1542.7300$

Figure 5. a, b: Mascot result showed the best match with the protein sequence of hypothetical protein of $L$. reuteri. As per the mascot score histogram, protein score $\geq 75 \%$ are significant. Sequence similarity is available as an NCBI BLAST search of CUR41808.1 against nr ELETKLPLP DRETRRIIED NFQKIQDEIN KIESQMKK.

Query Length 37

\section{Descriptions}

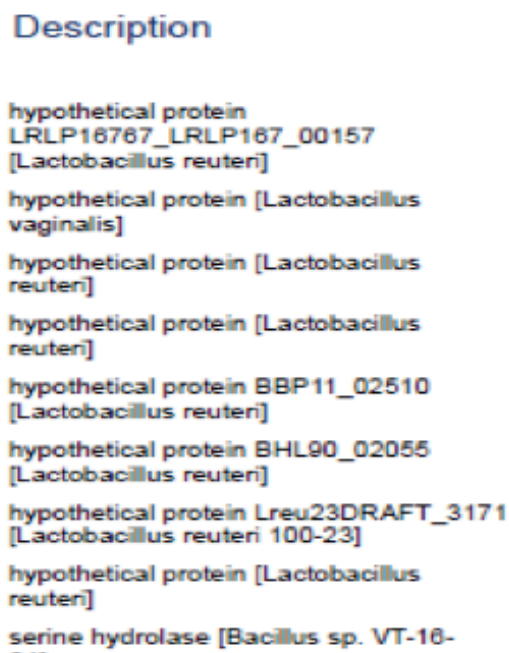

\begin{tabular}{|c|c|c|c|c|c|}
\hline $\begin{array}{l}\text { Max } \\
\text { Score }\end{array}$ & $\begin{array}{l}\text { Total } \\
\text { Score }\end{array}$ & $\begin{array}{l}\text { Query } \\
\text { Cover }\end{array}$ & $\begin{array}{l}\mathrm{E} \\
\text { value }\end{array}$ & $\begin{array}{l}\text { Per. } \\
\text { Ident }\end{array}$ & Accession \\
\hline 73.9 & 73.9 & $100 \%$ & $1 e-17$ & $100.00 \%$ & CUR41808.1 \\
\hline 49.3 & 49.3 & $100 \%$ & $8 e-0 B$ & $56.76 \%$ & WP 003717883.1 \\
\hline 42.0 & 42.0 & $89 \%$ & $6 e-05$ & $60.61 \%$ & WP 15370.0650 .1 \\
\hline 38.5 & 38.5 & $100 \%$ & 0.003 & $54.05 \%$ & WP 152742994.1 \\
\hline 38.1 & 76.2 & $81 \%$ & 0.006 & $63.33 \%$ & ocw61559.1 \\
\hline 38.1 & 38.1 & $81 \%$ & 0.006 & $63.33 \%$ & OTA48249.1 \\
\hline 7.7 & 37.7 & $81 \%$ & 0.007 & $63.33 \%$ & $E D \times 41660.1$ \\
\hline 7.7 & 37.7 & $100 \%$ & 0.009 & $54.05 \%$ & WP 170090569.1 \\
\hline & 30.4 & $81 \%$ & 8.1 & $50.00 \%$ & WP 077114121.1 \\
\hline
\end{tabular}

\section{Graphic Summary}

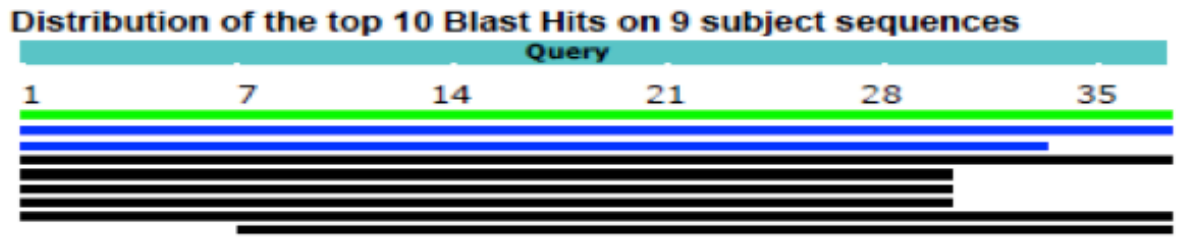

Figure 6. The BLAST analysis revealed, there are no match with the closely related nine peptides. The peptide showed no similarity with the already discovered bacteriocin as well. 

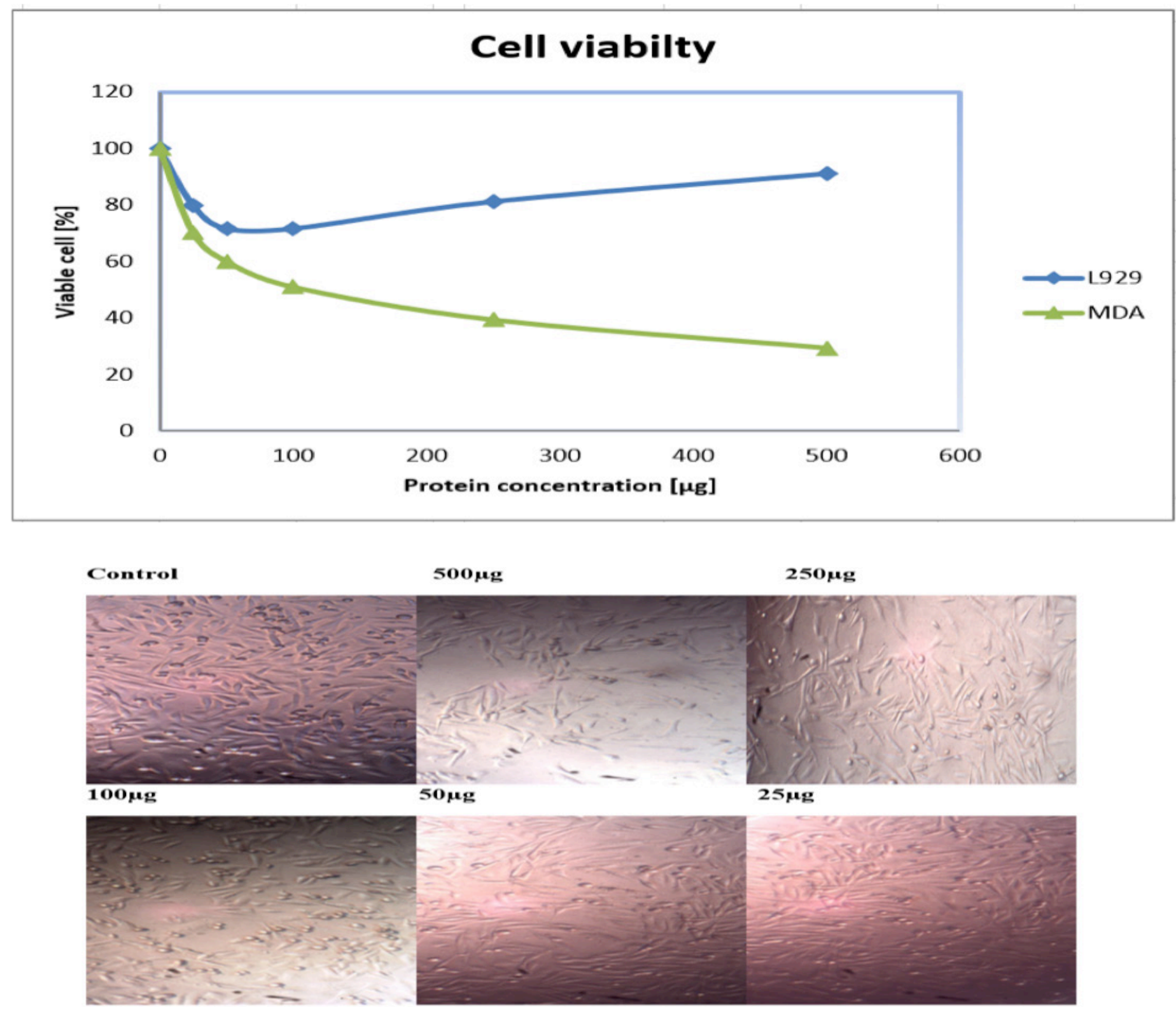

Figure 7. (a) The cell viability assay shows, with the increase in concentration of the peptide, the cells were killed when compared to the normal cell line L929, which was not affected by the peptide. (b) The MTT assay showed the cytotoxic activity of the peptide of interest. It depicts, in dose dependent manner, the cells were observed to get reduced in number. The cells were observed at $40 \times$ magnification.

report of this kind of peptide that was extracted and successfully purified from L. casei.

\subsection{Cytotoxic Activity of the Peptide Using MTT Assay}

The cell viability (\%) were plotted against peptide concentration $(\mu \mathrm{g} / \mathrm{ml})$ as shown in Figure $7(\mathrm{a})$. Blue line indicates Normal cell line L929 and green line indicates triple negative breast cancer cell line MDA-MB-231. In Figure 7(b) the MTT assay revealed a visible death of the cancer cells with the increase in sample concentration. The cells have been treated for 24 hours with the different concentration of sample, before measuring the cell viability at $570 \mathrm{~nm}$.

The $\mathrm{IC}_{50}$ value for MDA MB-231 cell line as reported by PilcoFerreto and Calaf [23], in the article "Influence of doxorubicin on apoptosis and oxidative stress in breast cancer cell lines". When treated with Doxorubicin, the $\mathrm{IC}_{50}$ value was found to be $543.52 \mu \mathrm{g} /$ $\mathrm{ml}$. So, with this back reference we have carried out the assay, with the cells treated with varied concentration of the peptide (50-500 $\mu \mathrm{g} / \mathrm{ml}$ ) along with a negative control (without any incorporation of the peptide of interest). We have found out the $\mathrm{IC}_{50}$ value for the 
peptide of interest is $108 \mu \mathrm{g} / \mathrm{ml}$ against MDA-MB-231 cell line, which showed five-fold better performance than the commercial drug available in the market.

This is the first study to report about this unnamed peptide, checked for its cytotoxic activity against triple negative breast cancer MDA-MB-231 by MTT assay. The $\mathrm{IC}_{50}$ value was showed to be $108 \mu \mathrm{g} / \mathrm{ml}$.

\section{CONCLUSION}

The peptide extracted using the simplest three-step purification process from the potent strain L. casei MH137744. The purified peptide of interest was found to be of $1.3 \mathrm{mg} \mathrm{ml}^{-1}$ of concentration. On partial identification, it did not show any match with any peptides in the databases, neither in the bacteriocin database as well. The unnamed protein product was checked for anti-cancer activity against major cancer cell line triple negative breast cancer MDA-MB-231 and the $\mathrm{IC}_{50}$ value was found to be $108 \mu \mathrm{g} / \mathrm{ml}$. The work will be further carried out solely with adenocarcinoma cell line A549 as another major cancer cell line and the structure and name of the unknown peptide shall be identified, in the future study.

\section{ACKNOWLEDGMENTS}

The authors are thankful to the VIT management for their continued support to carry out this research.

\section{CONFLICT OF INTEREST}

The authors report no financial or any other conflicts of interest in this work.

\section{FUNDING}

This work was financially supported by Vellore Institute of Technology.

\section{CONSENT TO PARTICIPATE}

The authors give consent to participate.

\section{ETHICAL APPROVAL}

This study does not involve experiments on animals or human subjects.

\section{AUTHOR CONTRIBUTIONS}

All authors made substantial contributions to conception and design, acquisition of data, or analysis and interpretation of data; took part in drafting the article or revising it critically for important intellectual content; agreed to submit to the current journal; gave final approval of the version to be published; and agree to be accountable for all aspects of the work.

\section{AVAILABILITY OF DATA AND MATERIAL (DATA TRANSPARENCY)}

Data are available on request to the corresponding author.

\section{REFERENCES}

1. Ferlay J, Soerjomataram I, Ervik M, Dikshit R, Eser S, Mathers CG, et al. GLOBOCAN 2012: estimated cancer incidence, mortality and prevalence worldwide in 2012. World Health Organization, Geneva, Switzerland, 2012.

2. Raguz S, Yagüe E. Resistance to chemotherapy: new treatments and novel insights into an old problem. Br J Cancer 2008;99(3):387-91.

3. Jenssen H, Hamill P, Hancock RE. Peptide antimicrobial agents. Clin Microbiol Rev 2006;19(3):491-511.

4. Arnison PG, Bibb MJ, Bierbaum G, Bowers AA, Bugni TS, Bulaj G, et al. Ribosomally synthesized and post-translationally modified peptide natural products: overview and recommendations for a universal nomenclature. Nat Prod Rep 2013;30(1):108-60.

5. Cotter PD, Ross RP, Hill C. Bacteriocins - a viable alternative to antibiotics. Nat Rev Microbiol 2013;11(2):95-105.

6. Kaur S, Kaur S. Bacteriocins as potential anticancer agents. Front Pharmacol 2015;6:272.

7. Riedl S, Rinner B, Asslaber M, Schaider H, Walzer S, Novak A, et al. In search of a novel target-phosphatidylserine exposed by non-apoptotic tumor cells and metastases of malignancies with poor treatment efficacy. Biochim Biophys Acta Biomembranes 2011;1808(11):2638-45.

8. Farkas-Himsley H, Cheung R. Bacterial proteinaceous products (bacteriocins) as cytotoxic agents of neoplasia. Cancer Res 1976;36(10):3561-7.

9. Cornut G, Fortin C, Soulières D. Antineoplastic properties of bacteriocins: revisiting potential active agents. Am J Clin. Oncol 2008;31(4):399-404.

10. Singh PK, Sharma V, Patil PB, Korpole S. Identification, purification and characterization of laterosporulin, a novel bacteriocin produced by Brevibacillus sp. strain GI-9. PloS One 2012;7(3):e31498.

11. Baindara P, Gautam A, Raghava GP, Korpole S. Anticancer properties of a defensin like class IId bacteriocin Laterosporulin10. Sci Rep 2017;7(1):1-9.

12. Saito H, Watanabe T, Tomioka H. Purification, properties, and cytotoxic effect of a bacteriocin from Mycobacterium smegmatis. Antimicrob Agents Chemother 1979;15(4):504-9.

13. De Giani A, Bovio F, Forcella M, Fusi P, Sello G, Di Gennaro P. Identification of a bacteriocin-like compound from Lactobacillus plantarum with antimicrobial activity and effects on normal and cancerogenic human intestinal cells. AMB Express 2019;9(1):1.

14. Mosmann T. Rapid colorimetric assay for cellular growth and survival: application to proliferation and cytotoxicity assays. J Immunol Meth 1983;65:55-63.

15. Sharma G, Dang S, Gupta S, Gabrani R. Antibacterial activity, cytotoxicity, and the mechanism of action of bacteriocin from Bacillus subtilis GAS101. Med Princ Pract 2018;27(2):186-92.

16. Slater T, Sawyer B, Sträuli U. Studies on succinate-tetrazolium reductase systems: III. Points of coupling of four different tetrazolium salts III. Points of coupling of four different tetrazolium salts. Biochem Biophys Acta 1963;77:383.

17. Zheng J, Wittouck S, Salvetti E, Franz CM, Harris H, Mattarelli P, et al. A taxonomic note on the genus Lactobacillus: description of 23 novel genera, emended description of the genus Lactobacillus Beijerinck 1901, and union of Lactobacillaceae and Leuconostocaceae. Int J Syst Evol Microbiol 2020;70(4):2782-858.

18. Daw MA, Falkiner FR. Bacteriocins: nature, function and structure Micron 1996;27(6):467-79.

19. Sabo SS, Converti A, Ichiwaki S, Oliveira RP. Bacteriocin production by Lactobacillus plantarum ST16Pa in supplemented whey powder formulations. J Dairy Sci 2019;102(1):87-99.

20. Ajesh K, Sudarslal S, Arunan C, Sreejith K. Kannurin, a novel lipopeptide from Bacillus cereus strain AK 1: isolation, 
structural evaluation and antifungal activities. J Appl Microbiol 2013;115(6):1287-96.

21. Coates J. Interpretation of infrared spectra, a practical approach In: Encyclopedia of analytical chemistry: applications, theory and instrumentation. John Wiley \& Sons, Ltd; Newtown, CT, 2006.

22. Zhang J, Yang Y, Yang H, Bu Y, Yi H, Zhang L, et al. Purification and partial characterization of bacteriocin Lac-B23, a nove bacteriocin production by Lactobacillus plantarum $\mathrm{J} 23$, isolated from Chinese traditional fermented milk. Front Microbiol 2018;9:2165
23. Pilco-Ferreto N, Calaf GM. Influence of doxorubicin on apoptosis and oxidative stress in breast cancer cell lines. Int $\mathrm{J}$ Oncol 2016;49(2):753-62.

How to cite this article:

Siddique JF, Vaithilingam M. Partial identification of a peptide from Lacticaseibacillus casei using MALDI TOF and it's cytotoxic activity against MDA-MB-231 cell line. J Appl Biol Biotech 2022; 10(02):42-51. 